\title{
Article \\ Oil Price and Stock Prices of EU Financial Companies: Evidence from Panel Data Modeling
}

\author{
Alexandra Horobet ${ }^{1, *}$, Georgiana Vrinceanu ${ }^{1}$, Consuela Popescu ${ }^{1}$ and Lucian Belascu ${ }^{2}$ \\ 1 Department of Business and Economics, Faculty of International Business and Economics, The Bucharest \\ University of Economic Studies, 010374 Bucharest, Romania; vrinceanugeorgiana16@stud.ase.ro (G.V.); \\ consuela.popescu@rei.ase.ro (C.P.) \\ 2 Department of Management, Marketing and Business Administration, Faculty of Economic Sciences, \\ "Lucian Blaga" University of Sibiu, 550024 Sibiu, Romania; lucian.belascu@ulbsibiu.ro \\ * Correspondence: alexandra.horobet@rei.ase.ro
}

Received: 25 September 2019; Accepted: 23 October 2019; Published: 25 October 2019

\begin{abstract}
Crude oil is an indispensable resource for the world economy and European Union (EU) countries are strongly dependent on oil imports. In a framework defined by generally positive correlations between oil and stock prices, the paper investigates the relationship between financial companies' stock prices and crude oil price using a sample of major financial companies headquartered in the EU. The link between stock prices and oil price risk is modelled using a set of macroeconomic variables that includes local stock market indices, the EUR/USD exchange rate, the oil imports dependency, inflation rate, and global volatility indices. We employ panel data as the base econometric model and an ARDL extension that is more appropriated for our research objectives. Our findings show that the EU financial sector is pervasively exposed to oil price changes over the long-run and this exposure is a component of financial companies' exposure to real economy risk factors, which points towards the key role of the financial sector in the EU economy in transmitting systemic shocks. At the same time, we detect signs of a different behavior of market investors over the short-versus the long-run concerning the valuation of financial companies' stock prices in relation to oil price and other macroeconomic variables, which raises distressing challenges for financial authorities.
\end{abstract}

Keywords: oil prices; stock prices; panel data analysis; ARDL; financial sector

\section{Introduction}

Crude oil is considered nowadays the most influential natural resource for the entire world economy. Moreover, it is a critical input for oil consumer countries and a substantial source of revenue for oil supplier countries; thus, any change or shock in the price of oil has the potential to impact the global economy. At the same time, given that oil price is determined at an international level, it is the price of reference for many sector industries, oil-, or non-oil related, which generates strong connections between them.

In this paper, we build on the idea that financial companies' exposure to oil price is a consequence of the countries' exposure to systemic risk at domestic, regional, and global level. In addition, based on the assumption that the stocks' market value represents the sum of the discounted expected future cash flows provided to investors by the issuer of the stock, oil prices influence economic growth, inflation, and overall market expectations of near-term up to long-term volatility, all of them having an indirect effect on the interest rate, which is critical for the discounting of future cash flows. Provided that interest rates increase, bonds will be more attractive to investors and the stock market prices are expected to fall. Exchange rate volatility is also expected to distress stock returns; for example, when EUR depreciates and USD appreciates, taking into account that American investors own shares 
in Europe, this might lead to a run-off from these shares in Europe. Additionally, stock indices are generally regarded as "barometers" of the markets hence we would expect a positive relationship between stock returns and local indices.

Changes in oil prices and, on the extreme side, shocks in prices, raise significant challenges to all economic actors that see themselves highly interconnected by a variable that, at first sight, impacts just a few of them. As such, although movements in the price of oil have undoubtedly the most significant impact on industries that are oil consumers, financial institutions might be exposed to oil price risk through their links with all economic sectors and industries either through traditional banking operations but also through the design and offer of hedging instruments and risk diversification tools. When we consider banking institutions, their performance is influenced, on the one hand, by changes in the probability of loan default of their customers that may originate from oil or non-related sectors, but also by the propensity towards investments of all market participants. Certainly, both of them are affected by the level of risk in the economy and, as long as oil price shocks increase the economy-wide risk level, this will have negative consequences on financial companies' performance. Furthermore, as long as the amount of money lent out from financial companies to the companies whose business relies heavily on oil is high, their exposure to changes in the oil price will be significant, but one should not forget that financial institutions are also well diversified and hedged with respect to the loans extended to the oil-and other non-oil related sectors. Moreover, the difficulties concerning oil price forecasting and the reality of open economies in a globalized world makes the study of the financial sector exposure to oil price changes interesting and thought-provoking. In this framework, an investigation of the largest financial institutions in the European Union, as the one proposed in this paper, offers a better understanding of the economy-wide role of these institutions in the transmission of risk.

Figure 1 illustrates the evolution of crude oil imports prices (USD per barrel of oil) in the European Union (EU) between 2000 and 2016. It is easily observable the surge in oil prices after 2000 until 2008, as well as between 2009 and 2011, while crude oil and petroleum imports in the European Union remained rather stable. Oil import prices dropped significantly after 2013 to reach approximately 40 US dollars per barrel in 2016, but the recent attacks on Saudi Arabia oil fields might trigger significant rises in the recent future.

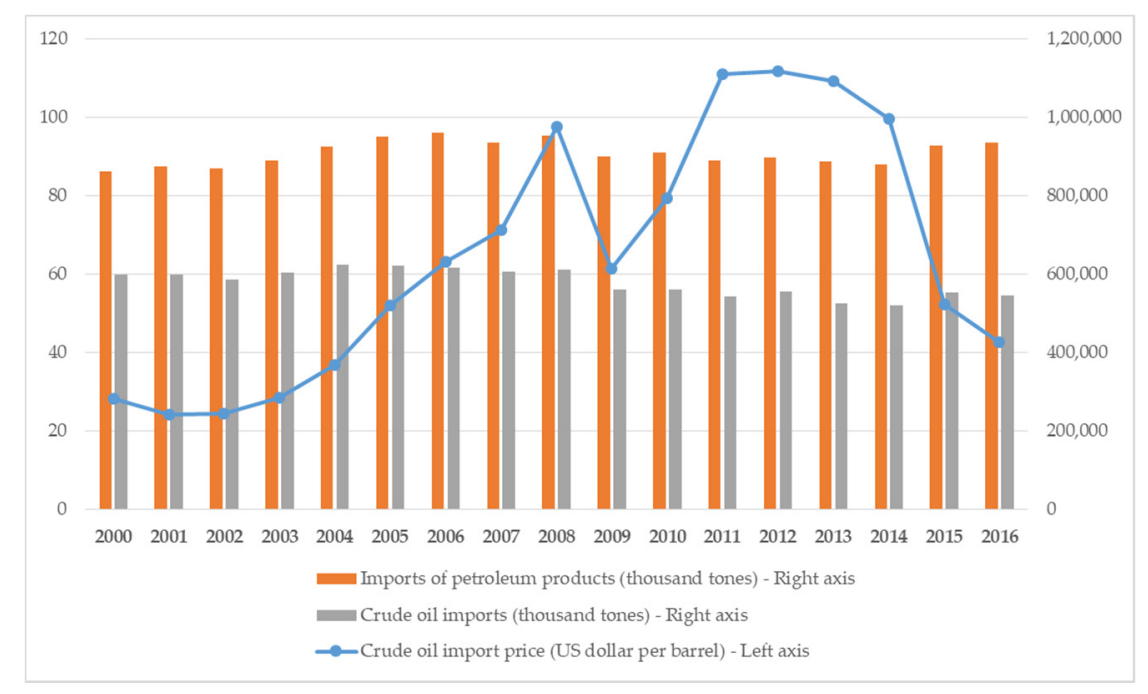

Figure 1. Crude oil import prices and imports of crude oil and petroleum products in the European Union, 2000-2016. Note: The crude oil import prices at the European Union Level (EU) level include oil import prices from Austria, Belgium, Czech Republic, Denmark, Finland, France, Germany, Greece, Ireland, Italy, Netherlands, Portugal, Spain, Sweden, and United Kingdom. Data source: Organization for Economic Cooperation and Development (OECD) and Eurostat. 
Given that EU member countries are mainly net oil importers, expectation is that when oil price rises the imports would generally decrease; however, considering that oil is such an important and not easily replaceable resource, it could happen that no effect is seen in the short-term. This, in turn, would be incorporated into higher risk-adjusted returns of financial companies. Incidentally, the European Union relies heavily on imports for oil consumption - in 2017, the ratio between net oil imports and gross inland energy consumption, known as the oil import dependency ratio, was $87 \%$ at the overall EU level, only slightly lower than the peak value of $89 \%$ recorded in 2015. Figure 2 shows the values of this ratio for EU member countries in 2017. In 18 out of $28 \mathrm{EU}$ countries, net oil imports levels were close to energy consumption levels, with dependency ratio values between $96 \%$ and $115 \%$. Only Denmark, with a rate of $-4 \%$ indicates that a net exporting country is an outlier in this EU landscape of heavy reliance on oil imports.

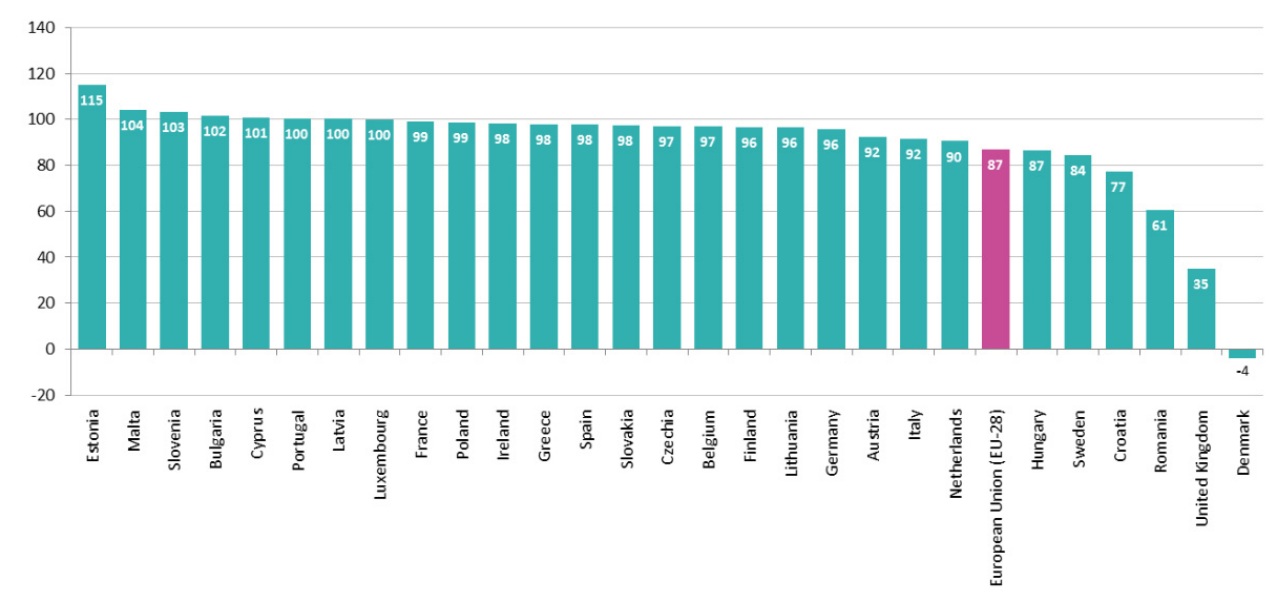

Figure 2. Oil import dependency rate in EU countries, 2017 (\%). Note: Oil import dependency is defined as the ratio between net imports and gross inland energy consumption. Data source: Eurostat-https://ec.europa.eu/eurostat/web/products-eurostat-news/-/DDN-20190828-1.

One of the best documented and consistent studies on the European Union oil dependency reveals other concerning issues for business and authorities alike [1]. Thus, the study shows that a high proportion of EU oil imports comes from regions that are politically unstable and have been prone to terrorism, conflicts, and wars (such as Russia, Nigeria and sub-Saharan Africa, Middle East, and North Africa). This generates a higher exposure of EU consumers and businesses to the risk of oil supply interruptions and shortages. Moreover, this exposure varies substantially across EU member states; of all countries, the Eastern EU countries (Poland, Slovakia, and Hungary) rely on Russia for over $90 \%$ of their crude oil supply, which makes this region highly vulnerable to both geopolitically and price-related oil shocks.

To the best of our knowledge, it is the first time in the literature when the short and long-term relationships between stock returns of financial companies, oil price, and several macroeconomic variables are studied using a panel ARDL model. Thus, our paper genuinely contributes both to the literature in the field and the more thorough understanding of the economic sectors' specific exposure to sources of systemic risk. Furthermore, we contribute to the debate on the particular role played by the financial sector in any open economy, even beyond its traditional functions.

The paper is structured as follows: Section 2 offers insights into the research directions and results in the existing literature, Section 3 presents the data used and the specifications of the model employed-an ARDL panel that is able to cope with the specific features of the data set and provides a useful understanding of the short-versus long-term relationship between oil and stock prices-, Section 4 outlines the most important and relevant results and Section 5 concludes and explores possibilities for future research. By far, the most important conclusion of our endeavor resides in 
confirming the critical role of the financial sector for the EU financial stability, given its position of intermediary and transmitter of economic shocks.

\section{Literature Review}

The empirical literature on this subject is currently growing and there are several studies that focus on the impact of oil price fluctuations on stock market returns. The current empirical evidence suggests that oil price changes lead to fluctuations in stock prices despite rather mixed results. As such, there are studies that found no relationship between oil price fluctuations and stock market returns, while others provided completely different findings.

One of the first tests of the impact of oil price changes on stock returns has been implemented for the Japanese economy [2]. The authors use an Arbitrage Pricing model to investigate the influence of Japanese macroeconomic factors—oil price among them—over the Japanese equity prices and find no risk premiums for oil price changes and unexpected changes in the currency rate allocated by market investors; they consider their results surprising given the high importance of international trade for the Japanese economy. Later, another study contradicts these findings and discovers that Japanese stock market returns are exposed to changes in oil prices [3]. The authors explain the difference between the two studies as stemming from the sample period and the research methodology-the latter paper uses a VAR model in the investigation. Moving to the US market, an investigation of the link between returns of oil futures contracts and stock returns during the 1980s using the same VAR methodology finds no correlation between the two variables, except for the returns of oil companies [4]. As a result, the authors propose the use of oil futures contracts in stock portfolios as good diversification tools. Enlarging the examination of the oil-stock price relationship to other developed economies, Jones and Kaul [5] find that the United States and Canadian stock prices react to changes in oil prices and this reaction is explained by the impact of oil price shocks on real cash flows, but the same pattern cannot be found for United Kingdom and Japanese stock prices; in the latter case, oil price shocks' impact on stock prices are larger than the changes in real cash flows or expected returns.

In a more recent research conducted on the Chinese market, oil price shocks are not found to significantly impact real stock returns of the most important Chinese equity indices, but the impact is significant in the case of an index of stocks from the manufacturing sector and of some oil companies [6]. Somehow in the same vein, an analysis of the impact of crude oil price shocks on stock market returns from United Kingdom, France, and Japan between 1989 and 2007, which uses a more sophisticated methodology-wavelet analysis coupled with a Markov Switching Vector Autoregressive (MS-VAR) approach, shows that shocks in oil prices do not negatively affect the recession phases in the stock market (with the exception of Japan) [7]. Contrarily, the same shocks are able to reduce the moderate and/or expansion phases of the stock markets, although this is only a temporary effect.

One of the most influential papers indicating an important role of oil price volatility in negatively influencing real stock returns concludes that changes in oil prices are able to explain a larger part of the forecast error variance in real stock returns in a VAR model compared to interest rates [8]. Moreover, the same author finds consistent evidence that shocks in oil price volatility impact asymmetrically the economy. On the same line, but this time using non-linear model specifications, Ciner [9] points toward a non-linear impact of oil price shocks on the S\&P 500 stock index returns. Moreover, the author documents a feedback relation from the stock index to oil futures markets, particularly in the 1990s, which highlights the significant interdependence between financial and real markets in the United States.

An interesting study examines the Granger-causal relationships between oil price fluctuations and global stock returns using time-varying causality tests in mean and in variance by splitting the sample into emerging and developed countries [10]. Its main finding consists in revealing that the relationship between oil prices and stock markets depends on the economic cycles' phases. Thus, during economic downturns there seems to be a volatility spillover from G7 stock markets to crude oil prices (due to increased overall uncertainty). The same conclusion is obtained in the case of emerging 
markets, even though of a different magnitude. The causal link from oil price volatility to G7 stock returns volatility also shows up during turbulent times (1994, 1999, and 2007-2009), but this finding is not supported in the case of emerging countries. Nevertheless, during late 2014 and late 2015, crude oil prices caused increased volatility in emerging stock markets' returns, a phenomenon which disappeared afterwards. What is also interesting is the volatility spillover experienced from G7 stock markets to emerging stock markets in the period before the global financial crisis, a relationship that ended in the post-crisis period and became very weak afterwards.

In addition to research that examines the general impact of oil price volatility and shocks on various economies, there are important results obtained as a result of investigations concerning the effects of oil price changes on stock returns from various economic sectors and industries. For example, Dominioni et al. [11] investigated the relationship between oil and renewable energy stock prices between 2006 and 2016 using an integrable non-autonomous Lotka-Volterra model. They discovered that the relationship between oil price and renewable energy sources stock prices is characterized by major structural breaks taking place in 2008 and around 2013. Reboredo et al. [12] studied the relationship between oil price and stock market returns using daily data based on the aggregate S\&P 500 and Dow Jones Stoxx Europe 600 indexes and US and European industrial sectors (banking, automobile and parts, chemical, oil and gas, telecommunications, industrial goods, utilities, technologies) from 2000 to 2011. Using wavelet multi-resolution analysis authors discovered that oil price changes have little effect on stock market returns in the pre-crisis period at both the aggregate and sectoral level. During the financial crisis, their findings show the positive interdependence between oil price shocks and stock returns at both aggregate and sector level.

At the same time, oil price fluctuation can be influenced by political and economic events that would lead to structural change, which on their side might generate biased estimations [13]. Thus, in a period of six months in 2017, several structural changes occurred in the Brent oil price. The results indicate a cointegrating relationship (positive or negative) between oil price and VIX (a global volatility index) or OVX (CBOE crude oil volatility index) depending on the period. All in all, OVX is considered to be a better predictor of oil price (as a measure of fear in the market) and authors advise investors to observe not only macroeconomic and political events when trying to predict oil price (for hedging or speculating purposes) but also the relationship between the latter and market volatility.

Considering that the study of oil price fluctuations impact on the stock market industrial sectors was rather scarce until now, it is meaningful to explore each industry's specific response to oil price changes, as each industry has its own particularities [14]. When it comes to the financial sector, results showed no clear pattern until now. Positive effects of oil price fluctuations were experienced on oil related and oil substitute products industries and negative effects on sectors that use oil but also inconsiderable effects on the financial sector. These findings may be explained by the supply chain dependency to oil markets as the key to explore the impact of oil price fluctuations in any sector [15].

A study on the relationship between oil price fluctuations and European stock returns using the Dow Jones Stoxx 600 index and 12 industrial sector indices from European countries shows that Financial, Oil and Gas, Industrials, Basic Materials, and Personal and Household Goods sectors present positive responses to oil price movements [16]. Additionally, in a subsequent study on the same relationship, it is revealed that the Financial and Consumer Goods sectors exhibit a negative response to oil price fluctuations [17]. Moreover, a study on the relationship between oil prices and the stock returns of US companies listed on the NYSE using a GARCH model also finds that oil price movements have asymmetric effects on stock returns taking into consideration the sector they originate from; for the Electricity, Engineering, and Financial sectors, the results were inconclusive [18]. Another study proves that most industries from European countries would benefit from the negative oil price movements. The authors found that the impact of oil prices shocks on 38 stock markets at the industry level notably varies along the European industries over the period 1983-2007 [19]. These results are also confirmed by Bagirov et al. [20]. They also demonstrate that the performance of listed oil and gas firms is significantly and positively impacted by crude oil prices; however, other factors impact the 
performance of unlisted firms. During the global financial crisis only the performance of the listed companies was negatively influenced by the situation.

Another recent study finds that stock market return and oil price are negatively correlated and oil price changes cause more volatility in stock returns. The relationship is explained by the fact that oil price represents an input for many industries, thus an increase in oil price leads to economic turmoil by creating inflation and unemployment [21]. Jinghzen et al. [22] analyzed the influence of oil price changes on stock returns of UK oil and gas companies at different time scales using the wavelet analysis. By decomposing the original return series into multiscale orthogonal components the changes can be better monitored in the short, medium, and long-term. Authors find that there is a positive relationship between the two variables which increases in the medium and long-term while in the short-run there is low interdependence.

Overall, the existing results revealed in the literature do not indicate a clear-cut and well-defined relationship between oil price changes and stock prices and returns, but suggests that this link has sectoral particularities that deserve to be better explored. In this framework, our research adds to the literature on the exposure of economic sectors to sources of systematic risk and highlights the (sometimes) neglected or less understood impact of a macroeconomic or even global variable-i.e., the oil price-on an economic sector that is not directly related to oil price trading and consumption, but may be a catalyst of risk transmission at the macroeconomic level.

\section{Materials and Methods}

We investigate the relationship between financial companies' stock prices and oil prices using a sample of 76 financial companies headquartered in EU included in the Forbes 2000 Ranking of the World's Largest Public Companies [23]. Table A1 in Appendix A shows the financial companies selected for the analysis, originating from six industries (Consumer financial services, Diversified insurance, Investment services, Major Banks, Regional Banks, Thrifts, and Mortgage Finance) and from 16 EU member countries (Austria, Belgium, Denmark, Finland, France, Germany, Greece, Hungary, Ireland, Italy, Netherlands, Poland, Portugal, Spain, Sweden, and the United Kingdom).

The macroeconomic set of explanatory variables is presented in Tables 1 and 2. It includes Brent crude oil price, local stock market indices, EUR/USD exchange rate (EUR as base currency), the oil imports dependency ratio-defined as the ratio of imports of oil and oil products to the total imports —and the harmonized index of consumer prices (HICP)—as a measure of consumer price inflation-for each headquarter country, VIX-a real-time market index that represents the market's expectation of 30-day forward-looking volatility (it measures market risk, fear, and stress) and VSTOXX-based on EURO STOXX 50 real-time options prices, is designed to reflect the market expectations of near-term up to long-term volatility by measuring the square root of the implied variance across all options of a given time to expiration. While VIX is a measure of global volatility and widely used for such purpose, VSTOXX incorporates the perception of market investors regarding the volatility of European equity markets.

Table 1. Variable description.

\begin{tabular}{cccc}
\hline Variable & Notation & Measurement Unit & Data Source \\
\hline Stock prices & P & EUR & Forbes, Bloomberg \\
\hline Oil prices & OIL & USD per & Bloomberg \\
\hline Exchange rate & FX & EUR/USD (EUR as base currency) & Bloomberg \\
\hline Consumer price index/Inflation rate & HICP & Units & Eurostat \\
\hline Oil imports dependency & IMP & Percentage & UN Comtrade Database \\
\hline Market volatility & VIX & Units & Bloomberg \\
\cline { 2 - 4 } & VSTOXX & &
\end{tabular}

Source: Authors' work. 
Table 2. Local stock market indices.

\begin{tabular}{cc}
\hline Country of Financial Company's Headquarters & Local Stock Market Index \\
\hline Austria & ATX \\
Belgium & BEL20 \\
Denmark & OMX Copenhagen all shares \\
Finland & OMX Helsinki \\
France & CAC Large 60 \\
Germany & DAX \\
Greece & Athens General Composite (ATG) \\
Hungary & Budapest SE (BUX) \\
Ireland & ISEQ Overall \\
Italy & FTSE Italia All Share \\
Netherlands & AEX All Share \\
Poland & WIG \\
Portugal & PSI 20 \\
Spain & IBEX 35 \\
Sweden & OMX Stockholm \\
United Kingdom & FTSE-All Share \\
\hline
\end{tabular}

Source: Authors' work.

All data has a monthly frequency and was included in our analysis in logarithmic form in order to mitigate the different measurement units across variables. The period under investigation is January 2010 to December 2018. Table 3 presents the common descriptive statistics of the data series.

Table 3. Descriptive statistics.

\begin{tabular}{cccccccc}
\hline Variable & Mean & Median & Maximum & Minimum & Standard Deviation & Skewness & Kurtosis \\
\hline Stock price & 266.068 & 18.319 & 59921.060 & 0.144 & 1909.682 & 20.960 & 527.265 \\
Oil price & 64.185 & 63.595 & 94.012 & 28.329 & 17.058 & -0.138 & 1.751 \\
EUR/USD & 1.243 & 1.249 & 1.480 & 1.052 & 0.114 & 0.000 \\
HICP & 99.193 & 99.800 & 107.800 & 87.780 & 3.510 & 1.760 \\
Oil imports dependency & 0.1053 & 0.095 & 0.414 & 0.022 & 0.055 & -0.618 & 3.529 \\
Local indices & 6889.808 & 4547.812 & $26,255.000$ & 29.439 & 6708.770 & 2.047 & 8.876 \\
VIX & 13.924 & 12.956 & 32.093 & 8.050 & 4.346 & 1.238 & 3.607 \\
VSTOXX & 21.960 & 21.050 & 46.680 & 11.990 & 6.195 & 1.512 \\
\hline
\end{tabular}

Source: Authors' calculations.

Taking each variable separately, expectation is that oil price will influence in a positive way companies' stock returns as an increase in the former might create leverage investments in stocks leading to a higher demand and thus an increase in overall stock price for oil companies. Consequently, for companies in the same business network, i.e., financial companies, this might build up their stock price as they are directly influenced by cash flows of oil companies. When general economic prospects, as reflected in local stock market indices, are good, we expect financial companies' stock prices to go up and vice-versa, given their general exposure to market risk. As EU economies are generally net oil importers, a depreciation of the EUR against the USD means bad news for oil importers (sign is expected to be negative in this case). The majority of these countries being net importers of oil an increase in imports of oil would have as an effect a higher market risk and a lower stock return. At the same time, expectation may be that when oil price rises the imports would generally decrease; however, considering that oil is an important and not easily replaceable resource, it could happen that no effect is seen in the short-term.

As HICP measures inflation, expectation is that it can either positively or negatively impact stocks, depending on the ability of the investor to hedge inflation risk and the government's fiscal policy. At the same time, during economic contractions, high inflation leads to low stock returns (spillover effect), which shows the negative relationship between the consumer price index-as a measure of inflation and stock returns [24]. VIX and VSTOXX would normally impact in a negative way stock returns as both of them designate market volatility and empirical evidences show that higher market volatility is typically associated to lower returns $[25,26]$.

We employ panel data as the base econometric model as it helps control for heterogeneity of cross-section units (companies' stock prices in our case) over time but also helps in obtaining more 
unbiased estimations. For this paper, an autoregressive distributed lag (ARDL) specification is used, which is a standard least square estimation that includes lags of both the dependent and independent variables. The ARDL framework examines cointegrating relationships between variables and allows for a long-run versus short-run view over the link between variables; thus, the ARDL specification results in a dynamic model where the effect of regressors on the dependent variable occurs over time and not immediately $[27,28]$.

The equation of the ARDL $\left(p, q_{1}, q_{2} \ldots q_{n}\right)$ model, where $p \geq 1$ and $q \geq 0$-assuming that the lag order $q$ is identical for all variables in the vector $\mathrm{X}$, is:

$$
Y_{i t}=\sum_{j=1}^{p}\left(\alpha_{i j} Y_{i, t-j}\right)+\sum_{j=0}^{q}\left(\delta^{\prime} i j X_{i, t-j}\right)+\mu_{i}+\varepsilon_{i t}
$$

where $Y$ is the stocks' price and the dependent variable, while $X$ is the vector of explanatory variables: Brent crude oil price (OIL), local stock market indexes (IND), EUR/USD exchange rate (FX), the oil imports dependency (IMP), the harmonized index of consumer prices (HICP), VIX, and VSTOXX. $\alpha_{i, j}$ and $\delta^{\prime} i j$ are the coefficients associated with a linear trend, lags of $Y$, and lags of the $q$ regressors $X$ for $j$ $=0, \ldots q, \mu_{i}$ is the short-run coefficient and $\varepsilon_{i t}$ is the error term.

Equation (1) allows for the parameters to vary between units and they can be estimated using the mean group estimator per company and then the average for the group [28]. The pooled mean group (PMG) allows for the short-run parameters to vary across companies but makes the long-run parameters homogeneous [29]. The PMG estimation is also consistent from the point of view of variable endogeneity, as an alternative to the more traditional Arellano-Bond GMM dynamic panel estimation $[30,31]$. If we reparametrize (as a way to demonstrate the short-run dynamics but also the long-run relationship of the underlying variables) the model we obtain is:

$$
\Delta Y_{i t}=\varphi_{i}\left(Y_{i, t-1}-\beta_{i}^{\prime} X_{i, t}\right)+\sum_{j=1}^{p-1}\left(\alpha_{i j}^{*} \Delta Y_{i, t-j}\right)+\sum_{j=0}^{q-1}\left(\delta_{i j}^{* \prime} \Delta X_{i, t-j}\right)+\mu_{i}+\varepsilon_{i t}
$$

where $\beta_{i}$ is a vector of interest which is used to measure the long-run impact of the regressors on the returns of stocks and $\varphi_{i}$ is the error corrector mechanism impact on the dependent variable, $\varepsilon_{i t}$ is the error term, and the rest of the parameters are short-run coefficients $\left(\mu_{i}, \delta^{\prime} i j\right)$.

Various authors have used in their estimations endogeneity tests for ARDL models, (see [32,33], for example), but although panel ARDL modelling does not intrinsically embed a test of variable endogeneity, this problem is unlikely to arise as long as the errors are serially uncorrelated because the regressors are at their lagged levels. Additionally, as long as cointegration is present, the OLS regression is consistent. On the same vein, the ARDL model produces consistent coefficients despite the possible presence of endogeneity because it includes lags of dependent and independent variables [29,34].

ARDL models have been used for decades to investigate the relationships between economic variables given their ability to decipher short-versus long-term connections between variables [35-37]. The oil-stock price link has not been an exception. Thus, Donggyu et al. [38] use the non-linear autoregressive distributed lag (ARDL) approach to test whether there is any relationship between oil price and stock prices of renewable energy firms. They find that oil price changes have asymmetrical effects on renewable energy stock prices in the short-run but not in the long-run. Moving further, another study confirmed both the existence of a long-and short-term relationship between the Romanian energy market and the capital market using, among others, an ARDL model, on the basis of a mixture between stationary and non-stationary time series [39]. In addition to this, another research found that in the long-run oil price, similar to interest rates and real effective exchange rates, has a negative impact on Malaysia's stock returns, while industrial production has a positive impact [40]. Results of another study using ARDL confirm that both in the long-and short-run there is a negative relationship between Shanghai stock returns and oil price [41]. 
In order to choose the most appropriate model of the long-run underlying equation, it is important to determine the optimum lag length by selecting the model with the smallest Akaike information criterion (AIC), Schwartz Bayesian criterion (SIC), or Hannah-Quinn criterion (HQ) or small standard errors and highest Adjusted $R^{2}$ [42]. These tests also account for robustness of the model and results.

As the regression equation gives only the short-run relationship between the variables and we are also interested in the long-run relationship between the variables, the concept of cointegration and reparametrization of the ARDL model into an error correction model becomes imperative [43]. Thus, with the help of ECM, Equation (2) provides both short-term and long-term information about the relationship between the dependent variable and the set of independent variables.

\section{Results and Discussion}

In order to see if the variables can be good predictors, tests for unit root were performed. Thus, Levin, Lin, Chu test (LLC), Breitung t-stat, Im, Pesaran and Shin W-Stat (IPS), ADF-Fisher Chi-square, and PP Fisher Chi-square tests were used. The advantage of using these tests is that the null hypothesis does not change for any of them, meaning the null hypothesis assumes common/individual unit root process.

The results in Table 4 show that the series of oil imports dependency, harmonized index of consumer prices, VIX and VSTOXX were stationary at level, while oil price, local indexes, EUR/USD exchange rate, and stock prices proved to be stationary at first difference. Considering that not all of the series are stationary at level, the use of ARDL model is more than justified as this technique is preferable when dealing with variables that are integrated at different orders [34,44].

Table 4. Unit root test of the variables.

\begin{tabular}{|c|c|c|c|c|c|c|}
\hline Variables & Order of Integration & LLC & Breitung & IPS & ADF & PP \\
\hline Stock return & 1 & $\begin{array}{c}-67.964 \\
(0.000)\end{array}$ & $\begin{array}{l}-28.608 \\
(0.000)\end{array}$ & $\begin{array}{c}-65.278 \\
(0.000)\end{array}$ & $\begin{array}{l}30.196 \\
(0.000)\end{array}$ & $\begin{array}{l}45.113 \\
(0.000)\end{array}$ \\
\hline Oil price & 1 & $\begin{array}{c}-57.337 \\
(0.000)\end{array}$ & $\begin{array}{c}-6.59729 \\
(0.000)\end{array}$ & $\begin{array}{c}-51.8059 \\
(0.000)\end{array}$ & $\begin{array}{c}2272.75 \\
(0.000)\end{array}$ & $\begin{array}{c}3493.71 \\
(0.000)\end{array}$ \\
\hline Local indices & 1 & $\begin{array}{c}-72.942 \\
(0.000)\end{array}$ & $\begin{array}{c}-23.0325 \\
(0.000)\end{array}$ & $\begin{array}{c}-62.5537 \\
(0.000)\end{array}$ & $\begin{array}{c}2893.06 \\
(0.000)\end{array}$ & $\begin{array}{l}4327.37 \\
(0.000)\end{array}$ \\
\hline EUR/USD & 1 & $\begin{array}{c}-61.924 \\
(0.000)\end{array}$ & $\begin{array}{c}-50.2184 \\
(0.000)\end{array}$ & $\begin{array}{c}-58.9631 \\
(0.000)\end{array}$ & $\begin{array}{c}2686.40 \\
(0.000)\end{array}$ & $\begin{array}{l}4874.68 \\
(0.000)\end{array}$ \\
\hline HICP & 1 & $\begin{array}{c}-74.759 \\
(0.000)\end{array}$ & $\begin{array}{c}-40.7939 \\
(0.000)\end{array}$ & $\begin{array}{c}-76.6122 \\
(0.000)\end{array}$ & $\begin{array}{l}3601.05 \\
(0.000)\end{array}$ & $\begin{array}{l}4882.43 \\
(0.000)\end{array}$ \\
\hline Oil imports dependency & 0 & $\begin{array}{l}-6.913 \\
(0.000)\end{array}$ & $\begin{array}{c}-11.2161 \\
(0.000)\end{array}$ & $\begin{array}{c}-9.52687 \\
(0.000)\end{array}$ & $\begin{array}{c}336.120 \\
(0.000)\end{array}$ & $\begin{array}{l}889.111 \\
(0.000)\end{array}$ \\
\hline VIX & 0 & $\begin{array}{c}-27.210 \\
(0.000)\end{array}$ & $\begin{array}{c}-3.61176 \\
(0.000)\end{array}$ & $\begin{array}{c}-18.8560 \\
(0.000)\end{array}$ & $\begin{array}{l}618.617 \\
(0.000)\end{array}$ & $\begin{array}{l}1081.68 \\
(0.000)\end{array}$ \\
\hline VSTOXX & 0 & $\begin{array}{c}-33.108 \\
(0.000)\end{array}$ & $\begin{array}{c}-17.3583 \\
(0.000)\end{array}$ & $\begin{array}{c}-16.8271 \\
(0.000)\end{array}$ & $\begin{array}{l}543.504 \\
(0.000)\end{array}$ & $\begin{array}{l}1103.24 \\
(0.000)\end{array}$ \\
\hline
\end{tabular}

Note: The null hypothesis is that the series is a unit-root process; $p$-values are reported in parentheses. Source: Authors' calculations.

The results of our panel ARDL estimations are summarized in Table 5. The table shows the estimation of the long-run and short-run coefficients by using only AIC as the lag length criterion, as results obtained using SC or HQ are very similar. Nevertheless, we discuss differences in our estimations obtained by using the three lag length criteria whenever they are relevant. It is important to mention that the long-run coefficients are constrained to be the same across financial companies, while the short-run coefficients are allowed to vary. The estimations whose results are presented in Table 5 are performed by varying the independent variables as a test for results' robustness. Thus, we vary regressors in order to examine the presence of oil price exposure when the panel regression specification is changed; the results are organized in the table from Model 1 to Model 8. 
Table 5. Results of panel ARDL estimations.

\begin{tabular}{|c|c|c|c|c|c|c|c|c|c|c|c|c|}
\hline \multirow{2}{*}{ Model } & \multirow{2}{*}{ Lag length } & \multicolumn{9}{|c|}{ Independent Variables } & \multirow{2}{*}{ SE } & \multirow{2}{*}{ LL } \\
\hline & & CQ1 & $\mathrm{CO}(-1)$ & FX & HICP & IMP & IND & OIL & VIX & VSTOXX & & \\
\hline \multirow{4}{*}{1} & \multirow{4}{*}{$\begin{array}{c}\text { ARDL } \\
(2,1,1,1,1,1,1)\end{array}$} & \multicolumn{9}{|c|}{ Long-run equation } & \multirow{4}{*}{0.159} & \multirow{4}{*}{$10,938.63$} \\
\hline & & na & na & $-1.280 *$ & -2.807 * & 0.243 ** & $1.288^{*}$ & $0.230 * *$ & -0.247 * & - & & \\
\hline & & & & & & rt-run equat & & & & & & \\
\hline & & $-0.047 *$ & -0.016 & $0.517^{*}$ & -0.197 & -0.030 ** & $1.315^{*}$ & 0.055 & $0.094^{*}$ & - & & \\
\hline \multirow{4}{*}{2} & \multirow{4}{*}{$\begin{array}{c}\text { ARDL } \\
(2,1,1,1,1,1,1)\end{array}$} & & & & & g-run equat & & & & & \multirow{4}{*}{0.156} & \multirow{4}{*}{$10,931.51$} \\
\hline & & na & na & $-1.339 *$ & $-3.653 *$ & $0.366^{*}$ & $1.162 *$ & 0.132 & - & $-0.383 *$ & & \\
\hline & & & & & & rt-run equat & & & & & & \\
\hline & & $-0.047 *$ & -0.016 & $0.517 *$ & -0.197 & $-0.030^{* *}$ & $1.315^{*}$ & 0.055 & $0.094^{*}$ & - & & \\
\hline \multirow{4}{*}{3} & \multirow{4}{*}{$\begin{array}{c}\text { ARDL } \\
(1,1,1,1,1,1,1)\end{array}$} & & & & & g-run equat & & & & & \multirow{4}{*}{0.180} & \multirow{4}{*}{8854.49} \\
\hline & & na & na & $-4.952 *$ & $-5.821 *$ & $1.328^{*}$ & - & $-0.396 * *$ & $-1.476 *$ & - & & \\
\hline & & & & & & rt-run equat & & & & & & \\
\hline & & $-0.042 *$ & na & $0.890 *$ & -0.548 ** & $-0.024 *$ & - & $0.117^{*}$ & $\begin{array}{l}-0.008 \\
\end{array}$ & - & & \\
\hline \multirow{4}{*}{4} & \multirow{4}{*}{$\begin{array}{c}\text { ARDL } \\
(2,1,1,1,1,1,1)\end{array}$} & & & & & g-run equat & & & & & \multirow{4}{*}{0.168} & \multirow{4}{*}{9158.56} \\
\hline & & na & na & $-4.591 *$ & $-9.452 *$ & $1.361^{*}$ & - & $-0.437 *$ & - & $-1.782 *$ & & \\
\hline & & & & & & rt-run equat & & & & & & \\
\hline & & $-0.046 *$ & -0.008 & $0.715^{*}$ & -0.154 & $-0.030 *$ & - & $0.144 *$ & - & $-0.066^{* *}$ & & \\
\hline \multirow{4}{*}{5} & \multirow{4}{*}{$\begin{array}{c}\text { ARDL } \\
(2,1,1,1,1,1,1)\end{array}$} & & & & & g-run equat & & & & & \multirow{4}{*}{0.160} & \multirow{4}{*}{$10,804.28$} \\
\hline & & na & na & - & $-0.110 *$ & $0.219 *$ & $1.300^{*}$ & $-0.126^{*}$ & $-0.161 *$ & - & & \\
\hline & & & & & & rt-run equat & & & & & & \\
\hline & & $-0.052 *$ & -0.008 & - & $-0.050 *$ & $-0.022 *$ & $1.330^{*}$ & $0.028^{*}$ & $0.069 *$ & - & & \\
\hline & & & & & & g-run equat & & & & & & \\
\hline 6 & ARDL & na & na & - & -0.311 * & $0.238^{*}$ & $1.254^{*}$ & $-0.152 *$ & - & $-0.161 *$ & 0160 & 1080428 \\
\hline 0 & $(2,1,1,1,1,1,1)$ & & & & & rt-run equat & & & & & 0.100 & $10,007.20$ \\
\hline & & -0.006 & $-0.100 *$ & - & $-0.020 *$ & $1.338^{*}$ & $0.031 *$ & $0.091 *$ & - & -0.006 & & \\
\hline & & & & & & g-run equat & & & & & & \\
\hline 7 & & na & na & $-0.574 *$ & - & $0.267^{*}$ & $1.242 *$ & $0.002 *$ & -0.112 * & - & 0158 & $10,886.99$ \\
\hline r & $(2,1,1,1,1,1,1)$ & & & & & rt-run equat & & & & & 0.150 & \\
\hline & & $-0.050 *$ & -0.011 & $0.504 *$ & - & $-0.025 *$ & $1.324^{*}$ & $0.056^{*}$ & $0.092 *$ & - & & \\
\hline & & & & & & g-run equat & & & & & & \\
\hline 8 & ARDL & na & na & $-0.506^{*}$ & - & $0.348^{*}$ & $1.238^{*}$ & -0.078 & - & $-0.128 *$ & 156 & 1087316 \\
\hline 0 & $(2,1,1,1,1,1,1)$ & & & & & rt-run equat & & & & & 0.150 & $10,010.10$ \\
\hline & & $-0.051 *$ & -0.009 & $0.376 *$ & - & -0.023 ** & $1.328^{*}$ & 0.051 & - & $0.104^{* *}$ & & \\
\hline
\end{tabular}

$*$ and ${ }^{* *}$ denote statistical significance at least at $1 \%$ and $5 \%$ level, respectively. SE and LL indicate the standard error of the regression and log likelihood, respectively. na-not available. "-"[M1] — the variable is not included in the model. All results are available from authors. Source: Authors' calculations. 
In the long-run, we notice statistically significant coefficients for all independent variables with signs that are consistent across the models. At the same time, we find statistically significant coefficients in the short-run equations as well, but not for all variables in all models and, more important, with different signs compared to the long-run equation. We further present and discuss the results for each of the eight models used in our estimations.

In Model 1, which uses VIX as a volatility measure, the long-run coefficient for oil price is positive, which shows that an increase in oil prices leads to an increase in stock prices. Regarding the EUR/USD exchange rate, we notice the opposite situation; for this variable, the coefficient is negative, which means that in the long-run an appreciation of the EUR would hurt financial companies' stock prices. Contrarily, in the short-run the oil price does not show a significant coefficient, but the cross-section coefficients indicate that 61 out of 76 cross-sections' coefficients are statistically significant (28 positive and 33 negative) - see Table 6. In other words, even if the short-run coefficient for oil price for the entire group of financial companies does not show statistical significance, there are enough cross-sectional features that induce specific exposures to oil price changes. By using SIC and HQ, in the long-run, oil price does not have a significant coefficient, but for the other variables we notice significant coefficients; moreover, the value of the coefficients and their signs are the same for all variables.

Table 6. Short-run statistically significant cross-section coefficients-number and signs.

\begin{tabular}{|c|c|c|c|c|c|c|c|c|c|c|c|c|c|c|c|c|c|c|}
\hline \multirow{3}{*}{ Model } & \multicolumn{18}{|c|}{ Independent Variables } \\
\hline & \multicolumn{2}{|c|}{ CQ1 } & \multicolumn{2}{|c|}{$\mathrm{CO}(-1)$} & \multicolumn{2}{|c|}{ FX } & \multicolumn{2}{|c|}{ HICP } & \multicolumn{2}{|c|}{ IMP } & \multicolumn{2}{|c|}{ IND } & \multicolumn{2}{|c|}{ OIL } & \multicolumn{2}{|c|}{ VIX } & \multicolumn{2}{|c|}{ VSTOXX } \\
\hline & + & - & + & - & + & - & + & - & + & - & + & - & + & - & + & - & + & - \\
\hline 1 & 2 & 74 & 34 & 33 & 45 & 10 & 0 & 3 & 31 & 35 & 74 & 1 & 28 & 33 & 55 & 15 & & \\
\hline 2 & 3 & 73 & 36 & 36 & 43 & 11 & 0 & 4 & 31 & 37 & 75 & 1 & 29 & 31 & - & & 52 & 21 \\
\hline 3 & 0 & 76 & \multicolumn{2}{|c|}{ na } & 48 & 9 & 0 & 1 & 15 & 49 & \multicolumn{2}{|c|}{-} & 48 & 11 & 8 & 68 & \multicolumn{2}{|c|}{-} \\
\hline 4 & 0 & 76 & 35 & 31 & 45 & 5 & 0 & 1 & 21 & 50 & & & 48 & 14 & & & 7 & 67 \\
\hline 5 & 1 & 75 & 43 & 33 & \multicolumn{2}{|c|}{-} & 27 & 49 & 40 & 36 & 75 & 1 & 35 & 41 & 51 & 25 & \multicolumn{2}{|c|}{-} \\
\hline 6 & 1 & 75 & 42 & 34 & \multicolumn{2}{|c|}{-} & 27 & 49 & 39 & 37 & 75 & 1 & 36 & 40 & \multicolumn{2}{|c|}{-} & 43 & 25 \\
\hline 7 & 2 & 74 & 40 & 36 & 56 & 20 & \multicolumn{2}{|c|}{-} & 36 & 40 & 75 & 1 & 37 & 39 & 56 & 20 & & \\
\hline 8 & 2 & 74 & 38 & 33 & 39 & 13 & \multicolumn{2}{|c|}{-} & 32 & 39 & 75 & 1 & 27 & 34 & \multicolumn{2}{|c|}{-} & 47 & 22 \\
\hline
\end{tabular}

Model 2 is similar to Model 1 but VIX is replaced by VSTOXX as a variable incorporating market volatility. This model shows no significant coefficient for oil price, but the EUR/USD exchange rate, local stock market index, and VSTOXX show statistically significant coefficients in both long-run and short-run equations. The VSTOXX results confirm the previously obtained result in the case of VIX, i.e., financial market volatility depresses stock prices. The same is true for the long-run coefficients identified for the currency rate and the market index. We also notice, as in the case of Model 1 estimations, that while in the long-run the signs for the EUR/USD exchange rate and VSTOXX are negative, in the short-run the signs are positive. This suggests that market investors might perceive differently the exposure of financial companies to various risk factors over the short versus the long-run, which is reflected in their assessment of prices and returns. Regarding the signs of the coefficients for the local stock market index, they are positive both in the long- and short-run, which confirms our hypothesis that good economic conditions, mirrored by stock market indexes increases, generate higher stock returns, regardless of the industry or economic sector. Again, as for Model 1, there is no significant difference between SIC and HQ in results.

Model 3 excludes the local stock market index and uses VIX as a volatility measure. In the short-run, as well in the long-run, we identify statistically significant coefficients for oil price, but with different signs. The fact that all long- and short-run coefficients for oil price become statistically significant when removing the local stock market index from the equation represents somehow a 
surprising result because it suggests that market investors do take into account an exposure of financial companies to oil price movements that is beyond the overall exposure to market risk. As such, this result might demonstrate the exposure of the financial sector to real economy risk factors. All criteria show significant coefficients for all variables in the long-run, as well as in the short-run, but except VIX. It is important to mention that the signs of the coefficients for the EUR/USD exchange rate are the same as in Models 1 and 2, i.e., negative in the long-run and positive in the short-run.

In Model 4 we removed the local stock market index and VSTOXX is now the measure of volatility this time. As in Model 3, we confirm the oil price exposure of financial companies in the absence of the local stock market index. The long- and short-run coefficients for oil price are statistically significant, but this time the statistical significance is found at least at $1 \%$ in all cases, not just in the short-run equation. The long-run coefficients are negative and the short-run coefficients are positive, similar to Model 3. All long-run coefficients are statistically significant for all criteria, except for the short-run coefficients for HICP and IMP; actually, the IMP coefficient is significant only by using AIC. We interpret this result as indicating a weak and residual exposure of financial companies' stock returns to both inflation risk and oil imports dependency of the country where the company is headquartered.

Model 5 excludes the EUR/USD exchange rate and uses VIX as volatility measure. In this case, all long-run coefficients for oil price are statistically significant and the signs are negative, as in Models 3 and 4 . In the short-run, all coefficient for oil price are significant, but only by using AIC the sign is positive; when SIC or HQ are used, the sign becomes negative. We interpret this result as a weak exposure of financial companies' stock prices to oil price in the absence of the exchange rate and as an intermediate role of the currency rate for the oil exposure. Moreover, under this specification, the coefficients for HICP became significant, as indicated by all criteria; this also points toward the intermediary role for the inflation rate in the relationship between stock and oil prices.

In Model 6 we eliminate the EUR/USD exchange rate and VIX from our panel equations, while using VSTOXX as volatility measure. The estimations are very similar to the ones for Model 5 . All long-run coefficients are statistically significant and the signs are negative, while all short coefficients are significant, but only by using AIC, and with a positive sign. When SIC and HQ are used, the short-run coefficients for oil price became negative. Again, all the coefficients for HICP are significant as a result of the removal of the exchange rate from the equations. We interpret this result as a confirmation of the results obtained with Model 5.

Model 7 removes HICP and VSTOXX from the panel equations. All long-and short-run coefficients for oil price are significant. Due to the presence of the local stock market index in the equations, we did not expect significant coefficients for oil price. Looking back at Models 1 and 2 results, where both HICP and local stock market index were included in the equations, the coefficients for oil were not significant (except using AIC in Model 1). Again, this result suggests the existence of strong exposure of financial companies' stock prices to changes in the price of oil. Thus, the exposure of the financial sector to real economy risk factors is reinforced by our findings.

The last model used, Model 8, differs from Model 7 by employing VSTOXX as volatility measure. Here, the coefficients for oil price are statistically significant in the long-run only by using SIC and HQ. As in Models 1 and 2, the short-run coefficients for oil price are not significant, but if we look at the cross-section coefficients we notice that more than half of our companies show statistically significant coefficients (see Table 6). For example, by using AIC, for 61 out of 76 financial companies the cross-section coefficient for oil price is significant; of them, for 27 companies the sign is positive and for 34 companies the sign is negative. In other words, even if the short-run coefficient for oil price for the entire group of financial companies does not show statistical significance, there are enough cross-sections features that induce exposure to oil price risk. Except oil price, all other variables show significant coefficients regardless of the criterion, which indicates a ubiquitous exposure of financial companies' stock prices to macroeconomic risk factors.

It is important to mention that we notice the existence of a statistically significant long-term cointegration relationship between variables, regardless of model. In addition, overall we find a 
connection between each independent variable and the dependent one, but particularities appear depending on each panel specifications but also on the long-versus the short-run perspective. The exposure of financial companies' stock prices to market risk is evident, as indicated by positive coefficients for the local market indices in both long-run and short-run equations. At the same time, inflation risk impacts the stock prices of financial companies, but the link between them is negative; this is in line with the negative relationship between interest rates and the price of financial securities, given the positive relationship between inflation and nominal interest rates. Another pervasive exposure of financial companies' stock prices is identified in the case of market volatility-either through VIX and VSTOXX-, but while volatility surges negatively influence stock prices over the long-run, the opposite is true for the short-run. This finding may point towards the short-run speculative behavior of market participants, while at the same incorporating a negative volatility-driven risk premium in the return of financial companies' stocks. A similar result is found in the case of the foreign exchange rate, with a negative long-run and a positive short-run impact of a EUR appreciation against the USD. This result is not necessarily surprising and we decipher here the augmented negative long-term impact of increases in the price of oil that, coupled with an appreciating currency, increase the systemic risk at macroeconomic level. At the same time, the positive short-term exposure to a EUR appreciation may highlight more the speculative actions in the financial market. Rather interesting, we see that a higher weight of oil and oil products in the countries' imports represents good news for financial companies' stock prices over the long-term and bad news over the short-term; this might be connected to a market perception that an increase in the importance of oil imports is related to a growth process of the economy that eventually boosts stock prices, including the ones of financial companies. Else ways, the short-run negative coefficients may be more likely linked to the increase in risk that is perceived once imports of oil and related products surge.

For what concerns the specific short-term exposure of EU financial companies to oil price changes, the distribution of cross-section coefficients across companies does not reveal any specific pattern based on signs, origin of headquarters, or financial services industry-see Table 6 . We find, though, that the number of cross-sections that show more positive than negative coefficients is higher than the cross-sections with the reverse situation (34 compared to 20); of them, 28 companies display statistically significant short-term coefficients for oil price in all panel specifications, of which 19 are positive (companies from all financial services industries and from Finland, Germany, Hungary, and Italy) and nine are negative (companies from the Diversified insurance, Investment services, Regional banks and Consumer financial services, and from Austria, Belgium, France, Germany, Netherlands, Poland, Spain, Sweden, and United Kingdom). These results indicate that EU financial companies' exposure to oil price risk has specificities across the financial services sector but also across countries; at the same time, many of these companies are conglomerates with diversified operations around the world in whose case the oil exposure might be well diversified as a component of global market risk and, as a result, no exposure is identified by the model.

Summarizing our findings, we consider the most important result of our research the fact that oil price displayed statistically significant coefficients when we excluded from the equations other variables, such as the local stock market index, HICP, or the EUR/USD exchange rate. This result indirectly highlights the pervasive exposure of economies from EU to risk factors through the financial sector channels, which raises alarming challenges from the perspective of macroeconomic and financial policies. In other words, our results reinforce the role of the EU financial sector as systemic risk transmitter.

In the case of panel regressions' standard errors (SE), smaller values are better because they indicate that the observations are closer to the fitted line. Contrarily, in the case of log likelihood (LL), the higher the value, the better the model. Taking these into account, we consider Model 1 (SE value is 0.159) as the best Model from our panel ARDL estimations. This model includes all variables and uses VIX to designate financial market volatility. 


\section{Conclusions}

Our study investigates the relationship between financial companies' stock prices and oil price using a sample of 76 financial companies headquartered in EU and included in the Forbes 2000 Ranking of the World's Largest Public Companies. The macroeconomic set of explanatory variables includes Brent crude oil prices, local stock market indices, EUR/USD exchange rate, oil imports dependency, HICP, VIX, and VSTOXX. We employ panel data as the base econometric model but also an ARDL specification that handles better cross-section specificities and provides a long-run versus a short-run perspective on financial companies' exposure to oil price risk. The investigation of the most important financial institutions in the European Union in terms of their stock price performance in relation to changes in oil prices and the application of the panel ARDL methodology are, in our opinion, the most important contributions we make to the debate that already exists in the literature. Thus, we provide financial institutions' managers with a better grasp of the risk triggers that influence their performance and point towards directions to improve the design of their hedging policies. Moreover, governments and authorities are offered an enlarged view over the links between macroeconomic risks and financial sector performance, which allows for ameliorated measures of economic policy that protect against shocks.

We find that financial companies headquartered in the European Union are ubiquitously exposed to oil price risk, but this exposure is a long-run one and comes hand in hand with the exposure of financial companies to real economy risk factors. Concurrently, the short-run exposure to oil price changes is less strong compared to the long-run exposure and bears specificities across companies, financial services industries, and countries. Moreover, our results suggest that market investors, although displaying a speculation-driven behavior over the short-term, adjust their risk premiums and valuation of financial companies' stock prices and returns over the long-run in order to incorporate macroeconomic risk circumstances.

Overall, our research reinforces the previous findings on the fundamental role of financial companies for the EU financial stability and highlights their relevance as transmitters of economic shocks, even outside the traditional financial landscape. At the same time, oil price is able to generate turbulences at economy-wide level, as long as even industries that are not oil producers and/or consumers display sensitivities to its fluctuations. These findings open several avenues for future research. One possible direction refers to the inclusion in our estimations of the non-oil energy sources, given the increase consumption of renewable primary energy in the European Union. An extension of our study to the most important EU companies from other industries is another possible line of future research, coupled with the inclusion of similar companies from other countries, in order to examine the robustness of our findings at an international level. As well, more sophisticated methodologies may be employed with the aim of providing further reliability to our estimates and of consolidating the knowledge on the exposure of the various economic sectors to risk sources.

Author Contributions: The authors contributed equally to this work.

Funding: This research received no external funding.

Conflicts of Interest: The authors declare no conflict of interest. 


\section{Appendix A}

Table A1. Financial companies by industry and country of headquarters.

\begin{tabular}{|c|c|c|c|c|}
\hline Industry & Country of Financial Company's Headquarters & Name of the Company & Market Value (2018) & Sales (2018) \\
\hline Consumer & Sweden & Fastighets Balder & $\$ 5.8 \mathrm{~B}$ & $\$ 772 \mathrm{M}$ \\
\hline Financial Services & United Kingdom & Melrose Industries & $\$ 12.4$ B & $\$ 11.5$ B \\
\hline \multirow{16}{*}{$\begin{array}{l}\text { Diversified } \\
\text { Insurance }\end{array}$} & Austria & Vienna Insurance Group & $\$ 3.6 \mathrm{~B}$ & $\$ 11.9$ B \\
\hline & Austria & Uniqa & $\$ 3.3 \mathrm{~B}$ & $\$ 6.7 \mathrm{~B}$ \\
\hline & Belgium & Aegeas & $\$ 10.2 \mathrm{~B}$ & $\$ 12.3 \mathrm{~B}$ \\
\hline & Finland & Sampo & $\$ 25.8 \mathrm{~B}$ & $\$ 9.5 \mathrm{~B}$ \\
\hline & France & AXA Group & $\$ 63.6 \mathrm{~B}$ & \$139.7 B \\
\hline & France & CNP Assurances & $\$ 16.5 \mathrm{~B}$ & $\$ 47.6 \mathrm{~B}$ \\
\hline & France & Scor & $\$ 8.1 \mathrm{~B}$ & $\$ 16.9$ B \\
\hline & Germany & Allianz & $\$ 102.3 \mathrm{~B}$ & $\$ 118.8 \mathrm{~B}$ \\
\hline & Germany & Munich Re & $\$ 36.3 \mathrm{~B}$ & $\$ 62.9 \mathrm{~B}$ \\
\hline & Germany & Nuernberger Beteiligungs & $\$ 922 \mathrm{M}$ & $\$ 5.1 \mathrm{~B}$ \\
\hline & Italy & Generali Group & $\$ 30.1$ B & $\$ 92.1 \mathrm{~B}$ \\
\hline & Italy & Unipol Gruppo & $\$ 3.7 \mathrm{~B}$ & $\$ 16.4$ B \\
\hline & Italy & Cattolica Assicurazioni & $\$ 1.6 \mathrm{~B}$ & $\$ 7.1 \mathrm{~B}$ \\
\hline & Netherlands & Aegon & $\$ 10.7$ B & $\$ 30.9$ B \\
\hline & Spain & Mapfre & $\$ 9.2 \mathrm{~B}$ & $\$ 25.2 \mathrm{~B}$ \\
\hline & United Kingdom & Willis Towers Watson & $\$ 22.9 \mathrm{~B}$ & $\$ 8.5 \mathrm{~B}$ \\
\hline \multirow{12}{*}{$\begin{array}{l}\text { Investment } \\
\text { Services }\end{array}$} & Belgium & Sofina & $\$ 6.8 \mathrm{~B}$ & $\$ 145 \mathrm{M}$ \\
\hline & France & Wendel & $\$ 6.1 \mathrm{~B}$ & $\$ 9.9 \mathrm{~B}$ \\
\hline & Germany & Deutsche Boerse & $\$ 24.2 \mathrm{~B}$ & $\$ 3.7 \mathrm{~B}$ \\
\hline & Germany & Wuestenrot \& Wuerttembergische & $\$ 2 \mathrm{~B}$ & $\$ 7.5 \mathrm{~B}$ \\
\hline & Netherlands & Exor & $\$ 15.9 \mathrm{~B}$ & $\$ 169.1$ B \\
\hline & Sweden & Investor $\mathrm{AB}$ & $\$ 36.1$ B & $\$ 4.7 \mathrm{~B}$ \\
\hline & Sweden & Industrivarden & \$10.1 B & $\$ 624 \mathrm{M}$ \\
\hline & United Kingdom & London Stock Exchange & $\$ 22.4 \mathrm{~B}$ & $\$ 2.8 \mathrm{~B}$ \\
\hline & United Kingdom & Investec & $\$ 6.3 \mathrm{~B}$ & $\$ 6 \mathrm{~B}$ \\
\hline & United Kingdom & 3i Group & $\$ 13.7 \mathrm{~B}$ & $\$ 590 \mathrm{M}$ \\
\hline & United Kingdom & St. James's Place & $\$ 7.7 \mathrm{~B}$ & $\$ 1.6 \mathrm{~B}$ \\
\hline & United Kingdom & TP ICAP & $\$ 2.1 \mathrm{~B}$ & $\$ 2.4 \mathrm{~B}$ \\
\hline \multirow{18}{*}{ Major Banks } & Austria & Erste Group Bank & $\$ 17 \mathrm{~B}$ & $\$ 11.5 \mathrm{~B}$ \\
\hline & Belgium & Dexia & $\$ 9 \mathrm{M}$ & $\$ 11 \mathrm{~B}$ \\
\hline & Denmark & Danske Bank & $\$ 16.6$ B & $\$ 15.4$ B \\
\hline & France & BNP Paribas & $\$ 68.7 \mathrm{~B}$ & $\$ 101.6$ B \\
\hline & France & Societe Generale & $\$ 24.5 \mathrm{~B}$ & $\$ 49.5$ B \\
\hline & France & Natixis & $\$ 18.6$ B & $\$ 17.5 \mathrm{~B}$ \\
\hline & Germany & Deutsche Bank & $\$ 18.1$ B & $\$ 42.3$ B \\
\hline & Netherlands & ING Group & $\$ 52.7 \mathrm{~B}$ & $\$ 39.4$ B \\
\hline & Spain & Santander & $\$ 84.1 \mathrm{~B}$ & $\$ 89.5 \mathrm{~B}$ \\
\hline & Sweden & Nordea Bank & $\$ 33.9$ B & \$15 B \\
\hline & Sweden & SEB AB & $\$ 21.2 \mathrm{~B}$ & $\$ 8 \mathrm{~B}$ \\
\hline & Sweden & Svenska Handelsbanken & $\$ 21.8 \mathrm{~B}$ & $\$ 7.4 \mathrm{~B}$ \\
\hline & Sweden & Swedbank & $\$ 18.6$ B & $\$ 6.6 \mathrm{~B}$ \\
\hline & United Kingdom & HSBC Holdings & $\$ 175.5 \mathrm{~B}$ & $\$ 64.3 \mathrm{~B}$ \\
\hline & United Kingdom & Lloyds Banking Group & $\$ 60.9$ B & $\$ 35.2 \mathrm{~B}$ \\
\hline & United Kingdom & Royal Bank of Scotland & $\$ 41.3 \mathrm{~B}$ & $\$ 22.2 \mathrm{~B}$ \\
\hline & United Kingdom & Barclays & $\$ 38 \mathrm{~B}$ & $\$ 28.2 \mathrm{~B}$ \\
\hline & United Kingdom & Standard Chartered & $\$ 28.9 \mathrm{~B}$ & $\$ 24$ B \\
\hline \multirow{27}{*}{ Regional Banks } & Austria & Raiffeisen Bank International & $\$ 8.9 \mathrm{~B}$ & $\$ 8.8 \mathrm{~B}$ \\
\hline & Belgium & KBC Group & $\$ 31.3 \mathrm{~B}$ & $\$ 15 \mathrm{~B}$ \\
\hline & Denmark & Jyske Bank & $\$ 3.4 \mathrm{~B}$ & $\$ 2.4 \mathrm{~B}$ \\
\hline & France & Credit Agricole & $\$ 38.4$ B & $\$ 52.2 \mathrm{~B}$ \\
\hline & Germany & Commerzbank & $\$ 11.4$ B & $\$ 15.2$ B \\
\hline & Greece & National Bank of Greece & $\$ 2 \mathrm{~B}$ & $\$ 2 \mathrm{~B}$ \\
\hline & Greece & Piraeus Bank & $\$ 873 \mathrm{M}$ & $\$ 2.9 \mathrm{~B}$ \\
\hline & Greece & Alpha Bank & $\$ 2.6 \mathrm{~B}$ & $\$ 3.8 \mathrm{~B}$ \\
\hline & Greece & Eurobank Ergasias & $\$ 1.8 \mathrm{~B}$ & $\$ 2.2 \mathrm{~B}$ \\
\hline & Hungary & OTP Bank & $\$ 12 \mathrm{~B}$ & $\$ 4.4 \mathrm{~B}$ \\
\hline & Ireland & AIB Group & $\$ 13 \mathrm{~B}$ & $\$ 3.8 \mathrm{~B}$ \\
\hline & Italy & Bank of Ireland & $\$ 7.2 \mathrm{~B}$ & $\$ 5.9 \mathrm{~B}$ \\
\hline & Italy & Intesa Sanpaolo & $\$ 45.9$ B & $\$ 28.1 \mathrm{~B}$ \\
\hline & Italy & Unicredit & $\$ 32 \mathrm{~B}$ & $\$ 31.1$ B \\
\hline & Italy & Mediobanca & $\$ 9.4 \mathrm{~B}$ & $\$ 3.5 \mathrm{~B}$ \\
\hline & Italy & UBI Banca & $\$ 3.6 \mathrm{~B}$ & $\$ 5.6 \mathrm{~B}$ \\
\hline & Italy & Banco BPM & $\$ 3.6 \mathrm{~B}$ & $\$ 6.1 \mathrm{~B}$ \\
\hline & Italy & BPER Banca & $\$ 2.3 \mathrm{~B}$ & $\$ 2.9 \mathrm{~B}$ \\
\hline & Italy & Credito Emiliano & $\$ 1.7 \mathrm{~B}$ & $\$ 4 \mathrm{~B}$ \\
\hline & Italy & Banca Popolare di Sondrio & $\$ 1.9 \mathrm{~B}$ & $\$ 2.3 \mathrm{~B}$ \\
\hline & Poland & PKO Bank Polski & $\$ 1.3 \mathrm{~B}$ & $\$ 1.3 \mathrm{~B}$ \\
\hline & Poland & Bank Pekao & $\$ 12.9$ B & $\$ 4.7 \mathrm{~B}$ \\
\hline & Portugal & Banco Comercial Portugues & $\$ 8.1 \mathrm{~B}$ & $\$ 2.6 \mathrm{~B}$ \\
\hline & Spain & BBVA-Banco Bilbao Vizcaya & $\$ 4.2 \mathrm{~B}$ & $\$ 3.2 \mathrm{~B}$ \\
\hline & Spain & CaixaBank & $\$ 41.6 \mathrm{~B}$ & $\$ 28.3 \mathrm{~B}$ \\
\hline & Spain & Banco de Sabadell & $\$ 19.9$ B & $\$ 12.4$ B \\
\hline & Spain & Bankinter & $\$ 6.4 \mathrm{~B}$ & $\$ 7.8 \mathrm{~B}$ \\
\hline $\begin{array}{c}\text { Thrifts and } \\
\text { Mortgage Finance }\end{array}$ & Germany & Aareal Bank & $\$ 7.4 \mathrm{~B}$ & $\$ 2.6 \mathrm{~B}$ \\
\hline
\end{tabular}

Data source: [23]. 


\section{References}

1. A Study on Oil Dependency in the EU. A Report for Transport and Environment. Cambridge Econometrics. 2016. Available online: https://www.camecon.com/wp-content/uploads/2016/11/Studyon-EU-oil-dependency-v1.4_Final.pdf (accessed on 4 September 2019).

2. Hamao, Y. An empirical examination of the arbitrage pricing theory: Using Japanese data. Jpn. World Econ. 1988, 1, 45-61. [CrossRef]

3. Kaneko, T.; Lee, B.S. Relative importance of economic factors in the U.S. and Japanese stock markets. J. Jpn. Int. Econ. 1995, 9, 290-307. [CrossRef]

4. Huang, R.D.; Masulis, R.W.; Stoll, H.R. Energy shocks and financial markets. J. Futures Mark. 1996, 16, 1-27. [CrossRef]

5. Jones, C.M.; Kaul, G. Oil and the stock markets. J. Financ. 1996, 51, 63-491. [CrossRef]

6. Cong, R.G.; Wei, Y.M.; Jiao, J.L.; Fan, Y. Relationships between oil price shocks and stock market: An empirical analysis from China. Energy Policy 2008, 36, 3544-3553. [CrossRef]

7. Jammazi, R.; Aloui, C. Wavelet decomposition and regime shifts: Assessing the effects of crude oil shocks on stock market returns. Energy Policy 2010, 38, 1415-1435. [CrossRef]

8. Sadorsky, P. Oil price shocks and stock market activity. Energy Econ. 1999, 21, 449-469. [CrossRef]

9. Ciner, C. Energy shocks and financial markets: Nonlinear linkages. SNDE 2001, 5, 1079. [CrossRef]

10. Cevik, E.I.; Atukeren, E.; Korkmaz, T. Oil Prices and Global Stock Markets: A Time-Varying Causality-In-Mean and Causality-in-Variance Analysis. Energies 2018, 11, 2848. [CrossRef]

11. Dominioni, G.; Romano, A.; Sotis, C. A Quantitative Study of the Interactions between Oil Price and Renewable Energy Sources Stock Prices. Energies 2019, 12, 1693. [CrossRef]

12. Reboredo, A.; Rivera-Castro, M.A. A wavelet decomposition approach to crude oil price and exchange rate dependence. Econ. Model. 2013, 32, 42-57. [CrossRef]

13. Lin, J.B.; Tsai, W. The Relations of Oil Price Change with Fear Gauges in Global Political and Economic Environment. Energies 2019, 12, 2982. [CrossRef]

14. Arouri, M.E.H.; Nguyen, D.K. Oil prices, stock markets and portfolio investment: Evidence from sector analysis in Europe over the last decade. Energy Policy 2010, 38, 4528-4539. [CrossRef]

15. Gogineni, S. Oil and the stock market: An industry level analysis. Financ. Rev. 2010, 45, 995-1010. [CrossRef]

16. Arouri, M.E.H. Does crude oil move stock markets in Europe? A sector investigation. Econ. Model. 2011, 28, 1716-1725. [CrossRef]

17. Degiannakis, S.; Filis, G.; Floros, C. Oil and stock returns: Evidence from European industrial sector indices in a time-varying environment. J. Int. Financ. Mark. Inst. Money 2013, 26, 175-191. [CrossRef]

18. Narayan, P.K.; Sharma, S.S. New evidence on oil price and firm returns. J. Bank. Financ. 2011, 35, 3253-3262. [CrossRef]

19. Scholtens, B.; Yurtsever, C. Oil price shocks and European industries. Energy Econ. 2012, 34, 1187-1195. [CrossRef]

20. Bagirov, M.; Mateus, C. Oil prices, stock markets and firm performance: Evidence from Europe. Int. Rev. Econ. Financ. 2019, 61, 270-288. [CrossRef]

21. Dhaoui, A.; Khraief, N. Empirical Linkage Between Oil Price and Stock Market Returns and Volatility: Evidence from International Developed Markets. Economics Discussion Papers. 2014. No. 2014-12, Kiel Institute for the World Economy. Available online: http://www.economics-ejournal.org/economics/ discussionpapers/2014-12 (accessed on 4 September 2019).

22. Jinghzen, L.; Klinkowska, O. Impact of oil price changes on stock returns of UK oil and gas companies: A wavelet-based analysis. SSRN Electron. J. 2017, 43. [CrossRef]

23. Forbes. Available online: https://www.forbes.com/global2000/list/\#tab:overall (accessed on 12 August 2019).

24. Celebi, K.; Honig, M. The Impact of Macroeconomic Factors on the German Stock Market: Evidence for the Crisis, Pre- and Post-Crisis Periods. J. Financ. Stud. 2019, 7, 18. [CrossRef]

25. Bae, J.; Kim, C.J.; Nelson, C.R. Why are stock returns and volatility negatively correlated? J. Empir. Financ. 2007, 14, 41-58. [CrossRef]

26. Blau, B.M.; Whitby, R.J. Range based volatility, expected stock returns and the low volatility anomaly. PLoS ONE 2017, 12, e0188517. [CrossRef] [PubMed] 
27. Pesaran, M.H.; Shin, Y. Generalized Impulse Response Analysis in Linear Multivariate Models. Econ. Lett. 1998, 58, 17-29. [CrossRef]

28. Pesaran, M.H.; Shin, Y.; Smith, R.J. Bounds testing approaches to the analysis of level relationships. J. Appl. Econ. 2001, 16, 289-326. [CrossRef]

29. Pesaran, M.H.; Shin, Y.; Smith, R.P. Pooled Mean Group Estimation of Dynamic Heterogeneous Panels. J. Am. Stat. Assoc. 1999, 94, 621-634. [CrossRef]

30. Arellano, M.; Bond, S. Some Tests of Specification for Panel Data: Monte Carlo Evidence and an Application to Employment Equations. Rev. Econ. Stud. 1991, 58, 277-297. [CrossRef]

31. Baek, J.; Choi, Y.J. Does Foreign Direct Investment Harm the Environment in Developing Countries? Dynamic Panel Analysis of Latin American Countries. Economies 2017, 5, 39. [CrossRef]

32. He, G.; Bai, L.; Ren, H. Analyst coverage and future stock price crash risk. J. Appl. Account. Res. 2019, 20, 63-77. [CrossRef]

33. Larcker, D.F.; Rusticus, T.O. On the use of instrumental variables in accounting research. J. Account. Econ. 2010, 49, 186-205. [CrossRef]

34. Nkoro, E.; Uko, A.K. Autoregressive Distributed Lag (ARDL) cointegration technique: Application and interpretation. J. Stat. Econom. Methods 2016, 5, 63-91.

35. Koyck, L.M. Distributed Lags and Investment Analysis; North-Holland: Amsterdam, The Netherland, 1954.

36. Almon, S. The distributed lag between capital appropriations and net expenditures. Econometrica 1965, 33, 178-196. [CrossRef]

37. Frances, P.H.; van Oest, R. On the Econometrics of the Koyck Model; Report 2004-07; Econometric Institute, Erasmus University: Rotterdam, The Netherland, 2004.

38. Donggyou, L.; Jungho, B. Stock prices of renewable energy firms: Are there asymmetric responses to oil price changes? Economies 2018, 6, 59.

39. Armeanu, D.S.; Joldes, C.C.; Gherghina, S.C. On the linkage between the energy market and stock returns: Evidence from Romania. Energies 2019, 12, 1463. [CrossRef]

40. Al-Hajj, E.; Al-Mulali, U.; Solarin, S.A. The influence of oil price shocks on stock market returns: Fresh evidence from Malaysia. Int. J. Energy Econ. Policy 2017, 7, 235-244.

41. Khan, M.K.; Teng, J.-H.; Khan, M.I. Asymmetric impact of oil prices on stock returns in Shanghai stock exchange: Evidence from asymmetric ARDL model. PLoS ONE 2019, 14, e0218289. [CrossRef]

42. Shrestha, M.B.; Bhatta, G.R. Selecting appropriate methodological framework for time series data analysis. J. Financ. Data Sci. 2018, 4, 71-89. [CrossRef]

43. Engle, R.F.; Granger, C.W.J. Co-integration and error correction: Representation, estimation, and testing. Econometrica 1987, 55, 251-276. [CrossRef]

44. Chudik, A.; Pesaran, M.H. Common correlated effects estimation of heterogeneous dynamic panel data models with weakly exogenous regressors. J. Econom. 2015, 188, 393-420. [CrossRef] 